\title{
Correction to: Balanced bright and dark field illumination for remote visual testing to detect cracks on pressure vessel of nuclear reactors
}

\author{
Takeshi Shimano $^{1}\left[\right.$ Keiichi Betsui $^{1}$
}

Published online: 27 July 2021

(c) The Optical Society of Japan 2021

\section{Correction to: Optical Review}

$$
\text { https://doi.org/10.1007/s10043-021-00673-5 }
$$

In the original publication Reference 3 has been published incorrectly. The correct Reference 3 is given in this Correction.

3. Pernick, B.J., et al.: Optical method for fatigue crack detection. Appl. Opt. 19(18), 3224-3229 (1980).

The original article has been corrected.
Publisher's Note Springer Nature remains neutral with regard to jurisdictional claims in published maps and institutional affiliations.

The original article can be found online at https://doi.org/10.1007/ s10043-021-00673-5.

Takeshi Shimano

takeshi.shimano.rb@hitachi.com

1 Center for Technology Innovation-Electronics and Instrumentation, Hitachi, Ltd., Research and Development Group, 1-280 Higashi-Koigakubo, Kokubunji, Tokyo 185-8601, Japan 